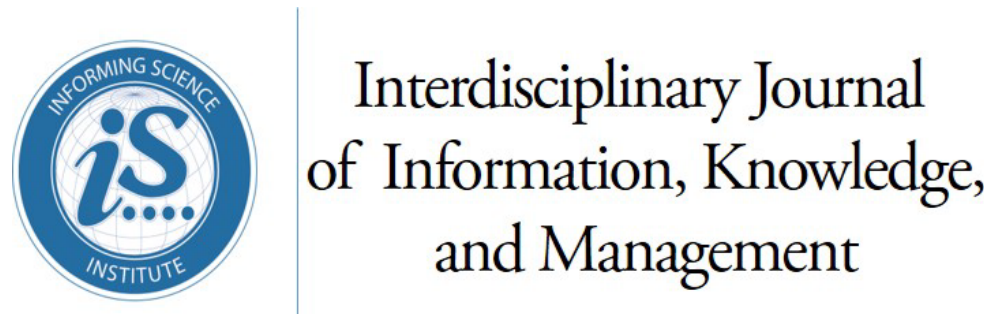

An Official Publication

of the Informing Science Institute

InformingScience.org

IJIKM.org

Volume 13, 2018

\title{
The Ways of Prosumers' KnOWLedge Sharing WITH ORGANIZATIONS
}

\author{
Ewa Ziemba* \\ Faculty of Finance and Insurance, \\ ewa.ziemba@ue.katowice.pl \\ University of Economics in Katowice, \\ Poland \\ Monika Eisenbardt \\ Faculty of Finance and Insurance, \\ monika.eisenbardt@ue.katowice.pl \\ University of Economics in Katowice, \\ Poland \\ * Corresponding author
}

\begin{abstract}
Aim/Purpose

The main purpose of this paper is to answer the research question whether the ways in which prosumers share their knowledge with enterprises and public organizations are in line with the ways in which enterprises and public organizations expect them to get engaged in knowledge sharing.

Background

Contemporary consumers do not wish to be passive consumers anymore. They want to satisfy their consumption needs by products' evaluation, co-designing, co-creation and co-reconfiguration. They can do that by sharing their knowledge with enterprises and public organizations. Such consumers are referred as 'prosumers'.

Methodology The research process consisted of a survey among prosumers and online observations of enterprises and public organizations. A final research sample includes 388 prosumers and 90 organizations.

Contribution This work contributes to existing research on utilizing consumers' knowledge in business and public organizations by identifying and examining ways of consumers' knowledge sharing with such organizations.

Findings It was found that there are differences between the ways in which prosumers share knowledge with organizations in comparison with the ways in which enterprises and public organizations expect them to get engaged in knowledge sharing. Prosumers mainly share their knowledge by evaluating products, whereas organizations mainly expect prosumers to get engaged in knowledge sharing by creating and designing products. In addition, it was found that enterprises
\end{abstract}

Accepted by Editor June Lu | Received: December 17, 2017 | Revised: April 14, May 4, May 26, 2018 | Accepted: May 29, 2018.

Cite as: Ziemba, E. \& Eisenbardt, M. (2018). The ways of prosumers' knowledge sharing with organizations. Interdisciplinary Journal of Information, Knowledge, and Management, 13, 95-115. https://doi.org/10.28945/4067

(CC BY-NC 4.0) This article is licensed to you under a Creative Commons Attribution-NonCommercial 4.0 International License. When you copy and redistribute this paper in full or in part, you need to provide proper attribution to it to ensure that others can later locate this work (and to ensure that others do not accuse you of plagiarism). You may (and we encourage you to) adapt, remix, transform, and build upon the material for any non-commercial purposes. This license does not permit you to use this material for commercial purposes. 
have bigger expectations as to prosumers' engagement in knowledge sharing than public organizations.

Recommendations This study provides practitioners with guidelines for prosumers' knowledge for Practitioners utilization, especially helping them understand which ways prosumers use to share knowledge.

Recommendation Researchers may consider the findings of the current study useful to conduct for Researchers further research on customer knowledge sharing with organizations using our approach and developing own research contexts.

Future Research This study examines Polish prosumers and organizations operating in the Polish market. It is advisable to extend the research to other countries and compare the results.

Keywords knowledge, knowledge sharing, prosumer, prosumption, consumer, product evaluation, product co-creation

\section{INTRODUCTION}

One of the most essential market phenomena is that the consumer-organization relationships have undergone transformations and changes (Calosci, 2017). These transformations and changes are caused by several factors, among which one can indicate the evolving role of consumers from passive recipients to active co-creators of value and the increase in the value of consumer knowledge for business and public organizations (Prahalad \& Ramaswamy, 2004; Taherparvar, Esmaeilpour, \& Dostar, 2014). Contemporary consumers do not wish to be passive consumers anymore. They want to satisfy their consumption needs by self-design, self-reconfiguration or even self-creation of products. It is possible when they are willing to share their knowledge, taking part in projects targeted at them by business and public organizations. In that way, by sharing their knowledge, consumers have an impact on product's development and its co-creation. Many enterprises have detected the value of consumers' knowledge in changing the consumers-business relationship. In turn, those consumers who are willing to share knowledge are known as 'prosumers' while the process in which they share the knowledge is referred to as 'prosumption'. Thus, prosumers' knowledge has become an essential intangible asset for every line of business which leads to better response to and respect toward customers, makes a contribution toward new and innovative products, as well as leads to the improvement of business value and enhances the competitiveness of businesses (Aghamirian, Dorri, \& Aghamirian, 2013; Brabham, 2012; Song \& Kang, 2016; Tsai, Tsai, Li, \& Lin, 2012; Tseng, 2016).

Great opportunities for prosumers in the field of knowledge sharing create an online environment. Particularly, a social media development and their omnipresence caused that more and more enterprises and public organizations are trying to engage prosumers in prosumer-oriented projects and as a result - to obtain proper knowledge from prosumers (Choi \& Shah, 2014; Jiebing, Bin, \& Yongjiang, 2013). On one hand, this knowledge should be connected with organizations' expectations and enable them to develop and upgrade products, and may contribute to business process improvement (Aghamirian, Dorri, \& Aghamirian, 2015; Trejo, Gutiérrez, \& Guzman, 2016). On the other hand, enterprises and public organizations should know as much as possible about prosumers. It may help them with choosing the way they should engage prosumers in knowledge sharing. In practice, the expectations of prosumers as to the ways of participation in the projects aimed at knowledge sharing vary more or less from the perception of enterprises or public organizations (Ziemba \& Eisenbardt, 2017). What is more, prosumers can be engaged in knowledge sharing by enterprises and public organizations. Thus, the ways in which enterprises try engaging prosumers may vary as well from the ways in which public organizations try engaging them. This situation might be the result of enterprises and public organizations having different business purposes and expectations connected with prosumers' knowledge. 
The above-mentioned issues are partially explored by Ziemba, Eisenbardt, and Mullins (Ziemba \& Eisenbardt, 2014, 2015; Ziemba, Eisenbardt, \& Mullins, 2017). Nonetheless, their reported outcomes are the result of questionnaire surveys that exclusively yielded responses from prosumers. Therefore, it is a prosumers' view of knowledge sharing with organizations. The authors of this paper, following an extensive review of the literature, did not uncover any deep studies related to organizations' point of view on these issues. Therefore, conducting research among prosumers as well as analyzing the ways in which enterprises and public organizations expect prosumers to get engaged in knowledge sharing may help fill in the gap in the existing body of knowledge.

Thus, this paper aims to answer the main research question whether the ways in which prosumers share their knowledge with enterprises and public organizations are in line with the ways in which enterprises and public organizations expect them to get engaged in knowledge sharing. Accordingly, the objectives of the paper are threefold. First, we identified and analyzed the ways of prosumers' knowledge sharing with business and public organizations, considering their gender and age, in terms of (1) evaluating products by scoring, (2) evaluating products by comments, and (3) creating and designing products. Second, we examined whether prosumers share their knowledge in the ways as expect by the enterprises and public organizations. Finally, we investigated the differences and similarities between enterprises and public organizations in the ways they expect prosumers to get engaged in knowledge sharing. In practical terms, organizations will gain insight from our findings about the ways in which prosumers share their knowledge in comparison with the ways in which they used to engage them in knowledge sharing.

The paper consists of four parts. The literature part discusses the value of prosumers' knowledge for organizations as well as briefly describes most important issues related to the ways of prosumers' knowledge sharing with enterprises and public organizations. Then the methodology part describes both stages of conducted research - the questionnaire survey and online observation. The third part is devoted to analyses of the ways of prosumers' knowledge sharing in the context of their and organizations' points of view. The study concludes with a discussion of the findings, implications, limitations, and avenues for further research.

\section{LITERATURE REVIEW}

A critical review of existing studies related to prosumption and prosumer, ways of knowledge sharing, value of prosumers' knowledge for organizations, as well as organizations' expectations for knowledge sharing, enabled examination of the ways of prosumers' knowledge sharing. The review embraced four bibliographic databases: Ebsco, ProQuest, Emerald Management, and ISI Web of Knowledge. In addition, some journals and Web materials dedicated to research on 'consumption' and 'prosumption' were also explored.

\section{THE VALUE OF PROSUMERS'KNOWLEDGE FOR ORGANIZATIONS}

Knowledge can be created inside the organization - by employees. For many years, it has been the one and only way of knowledge creation (Nonaka \&Takeuchi, 2000). Today, knowledge can be obtained from outside of enterprises or public organizations - from prosumers (Tseng, 2016).

'Prosumers' are those consumers who share their knowledge with organizations (Rayna \& Striukova, 2016; Ritzer, 2015). Thus, the process in which they share knowledge, thereby taking part in products evaluation and co-creation and in that way having an impact on processes improvement, is known as prosumption (Toffler, 1980; Xie, Bagozzi, \& Troye, 2008).

Prosumers' knowledge is becoming an increasingly important asset for contemporary organizations and is one of the most important contributors to improving added value and enhancing organizations' performance (Aghamirian et al., 2013; Cui \& Wu, 2015; Omotayo, 2015; Panni, 2015; Shihab \& Lestari, 2014; Taherparvar et al., 2014; Trejo et al., 2016). Practical cases confirm that enterprises and public organizations expect prosumers to share their knowledge through prosumer-oriented projects. The following are some typical examples: 
- Polish bank WBK has a portal facilitating knowledge and ideas sharing between the bank and prosumers. The bank offers tangible rewards expecting that prosumers would share their ideas concerning banks' products and services development;

- On the Streetcom, Polish recommendation's portal, a lot of enterprises expect that prosumers would share their knowledge as for them are offered numerous projects in which they can take part, for instance, (1) a project aimed at the mobile applications testing for two Polish banks (mBank and Millenium Bank) before these applications were launched on the market, (2) L'Oreal beauty cosmetics testing before these products were launched on the market, (3) a project during which prosumers were engaged in upgrading the functionality of the Polish school guide portal;

- Polish radio expected to engage prosumers to support the radio-presenters in the music choosing sphere, offering prosumers tangible incentives in return (Polish radio - EscaRock);

- Public administration offers prosumers many projects in which they expect prosumers to engage in such activities as: logo, poster or statue design, creation of graphical elements, opinion sharing, participative budget evaluation, etc. The best ideas are rewarded with tangible or intangible rewards.

By sharing knowledge, prosumers have an impact on products or services, frequently their shape, look, functionality, and quality. As encouraged by various incentives, they can use different ICT (information and communication technologies) for knowledge sharing. The enterprises expect that through prosumers engagement they can create new, innovative products or further develop the existing ones, consistent with prosumers' ideas. At the same time, they expect that the access to prosumers' knowledge would enable them to follow prosumers' needs in a quick and direct way (Aghamirian et al., 2013; Croteau \& Li, 2003; Katemukda \& Sudasna-Na-Ayudthya, 2015; Tseng, 2016). The challenge for organizations is, therefore, to get an access to prosumers' knowledge sources and to utilize prosumers' knowledge for improving their own business. Such challenge requires a holistic approach embracing various business, organizational, and technological issues (Ziemba, 2013). Four of them are paramount and are presented in Figure 1.

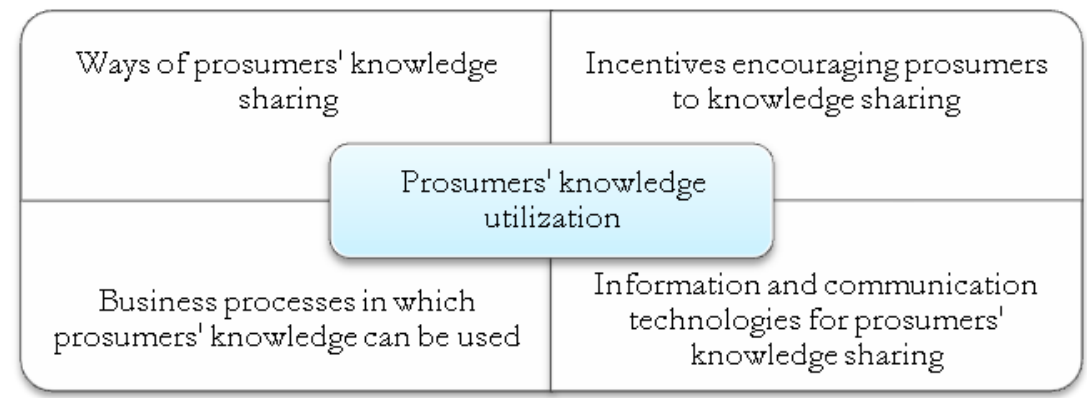

Figure 1. The Paramount Issues for Prosumers' Knowledge Utilization in Organizations (Ziemba \& Eisenbardt, 2017)

Figure 1 presents that for the utilization of prosumers' knowledge in enterprises and public organizations it is important to know the ways of prosumers' knowledge sharing (Bryant, 2011; Choi \& Shah, 2014). It is also crucial to know which incentives could encourage prosumers to engage in knowledge sharing (Ho \& Kuo, 2013; Löcker et al., 2014), which ICT prosumers prefer for knowledge sharing (Bayram \& Demirtel, 2014; Jiebing et al., 2013; Ritzer \& Jurgenson, 2010), as well as in which business processes prosumers' knowledge can be used for their improvement (Gibbert, Leibold, \& Probst, 2002; Prahalad \& Ramaswamy, 2004). A general analysis of the possibilities of prosumers' knowledge utilization by companies was provided by Ziemba \& Eisenbardt (2017). This paper focuses on the ways of prosumers' knowledge sharing via detailed analyses.

It is worth stressing that prosumers' attitude toward knowledge sharing may vary depending on their characteristics. That attitude could differ based on prosumers' gender and age. Today, the majority of prosumers share their knowledge using the Internet and social media, as they have become an inte- 
gral part of modern society (Gafni \& Golan, 2016). The research conducted by Ma and Yuen (2011) indicates a greater desire and more attention paid by men than women to form relationships and bonds on the Internet. However, in an experiment conducted in the Polish social media, based on the snowball technique, women far more eagerly shared knowledge than men (Mitręga, 2013). What is more, prosumers' engagement in knowledge sharing depends on direct incentives and personal benefits (Gafni, Geri, \& Bengov, 2014; Jelonek, 2013; Ziemba, Eisenbardt, Mullins, \& Grabara, 2017). Their own satisfaction or expectations to be recognized in some peer-groups could also be an incentive and, in turn, it may increase their engagement in knowledge sharing. No less important are ICT which prosumers can use to share knowledge. Today, social media have become increasingly significant channels for enterprises expecting prosumers' knowledge, as people share lots of information and knowledge in public social media such as Facebook, Twitter, and YouTube (Kettles, St. Louis, \& Steinbart, 2017). Taking into account the level and the way of ICT use by people, the literature specifies the following generations: Baby Boomers, X, Y, Z, Alpha and less clearly set in the time frame Generation C (McCrindle, 2015). Each of the mentioned generations defers from the previous one significantly, especially in the attitudes toward such fundamental issues as: consumption, work, education and the ways of gaining and sharing information and knowledge (Ziemba, Eisenbardt, \& Eisenbardt, 2016). Thus, the considerations presented above were the underpinnings for gender and generations analyses.

\section{THE WAYS OF PROSUMERS'KNOWLEDGE SHARING}

Bryant (2011) distinguishes two categories of prosumers based on their engagement in knowledge sharing, i.e. critics and creators. Critics are those prosumers who share their opinions, insights or experiences about products or services delivered by organizations, whilst creators actively engage in the processes of products' design or improvement. Ziemba \& Eisenbardt (2013) examined two types of prosumers by their relations with enterprises, i.e. feedback providers and value creators. Feedback providers evaluate products and services thorough rankings and pools as well as by giving opinions and comments, whereas value creators engage in the process of improving existing products as well as in the design and development of new ones. Other researchers identified that discussions and reviews are important tools which can help organizations gain knowledge from and about prosumers (Ford \& Mason, 2013; Taherparvar et al., 2014).

The way in which prosumers share their knowledge could be characterized as an action in which prosumers' knowledge is exchanged among prosumers and enterprises or public organizations. By undertaking this action prosumers share what they have learned and transfer what they know to enterprises or public organizations that have a business interest in it and have found this new knowledge to be useful for business improvement (Cheng, Ho, \& Lau, 2009). This action appreciates the value of knowledge when it is shared (Lichtenthaler, 2017). Taking into account the level of prosumers' engagement, it is possible to declare three main ways of prosumers' knowledge sharing, i.e., (1) evaluating products by scoring, (2) evaluating products by comments, (3) creating and designing products, which are presented in Figure 2. 


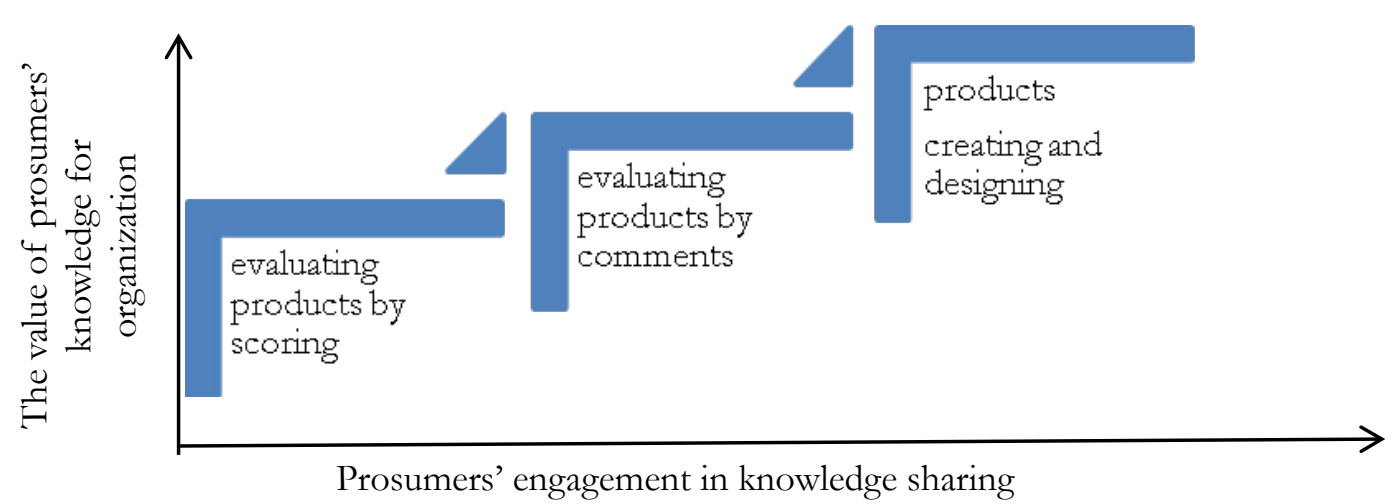

Figure 2. Main Ways of Prosumers' Knowledge Sharing.

Figure 2 presents that the prosumers' engagement as well as the value of prosumers' knowledge for enterprises or public organizations can vary depending on the way in which organizations expect prosumers to engage in knowledge sharing. The least prosumers' engagement concerns product evaluation by scoring. Often it is just a sole click on a particular scale indicating prosumers satisfaction or his/her opinion about a product. Thus, the disadvantage for enterprises could be the fact that they cannot know exact motives and triggers which made prosumers to indicate such a score. Nonetheless, the advantage is that it is very easy to draw some basic conclusions on the basis of prosumers' evaluations.

Evaluating products with comments could bring bigger value for organizations. In that way prosumers can share their knowledge about all issues important for them. Thus, prosumers' comments could be huge source of their opinions and knowledge, but the big challenge for organizations is to analyze them.

The greatest benefits and value for organization could be brought by the possibility of engaging prosumers in creating and designing products. In that way prosumers may share their knowledge and ideas about a product which they are using, evaluating, for instance, the functionality, reliability, or convenience of product's use. Thus, enterprises can obtain a lot of prosumers' ideas on the product which could lead to the development of that product. On the other hand, prosumers can be engaged in co-creation of new products. They can have an impact on the look, design, functionality, and usability of new products. In that way the value of prosumers' knowledge for enterprises is the biggest one.

It is possible to conclude, that prosumers who evaluate products by scoring or comments can be described as feedback providers, whilst prosumers who create and design products can be described as value creators (Ziemba \& Eisenbardt, 2013). This approach reflects a conviction that these represent important ways in which one can influence products and services. Comments posted on the Internet can be instrumental in making decisions on the extent and nature of modifications to all kinds of products. More than that, they could inspire a company or service provider to introduce improvements and enhancements even in cases where no modifications were previously considered as necessary. As a result, companies are able to respond promptly and effectively, and to align their business with concepts that would be difficult to discover in any other way.

The truth is that, in contributing their opinions, consumers very often do not think in terms of their usability for business purposes. All they do is share their thoughts and experiences with others, hoping to help them in that way - to reassure or alert them, or even to discredit certain products. What they do not often realize is that, by doing so, they help businesses at the same time (Yang \& Li, 2016; Yuan, Lin, \& Zhuo, 2016).

What is more, a prosumer is not just someone who reads and posts comments on the Internet. A prosumer is primarily a proactive consumer entering into a variety of interactions with businesses. Such interactions usually involve two kinds of activities: (1) prosumers' engagement in the process of 
improving and modernizing products that are already present on the market and are well known to consumers, and (2) prosumers' engagement in the design and development of new products through sharing original ideas, innovative concepts, and non-stereotype solutions. It is worth stressing, that the analyses of prosumers' engagement in prosumer-oriented projects should not be limited just to social media tools such as Facebook, YouTube, Twitter, and so on. Obviously, they are very popular and in turn one can find plenty of that kind of projects without much trouble (Fuchs, 2017; Goh, Heng, \& Lin, 2013). Prosumers' engagement may take a number of diverse forms, ranging from games and contests, through testing and evaluating, to serious initiatives aimed at encouraging them to design new products or suggest improvements to existing ones (Barger, Peltier, \& Schultz, 2016; Vashisht \& Pillai, 2017).

A detailed analysis of the literature indicated that researchers recognize the fact that knowledge is crucial for modern organizations' performance and development. Nonetheless, just a few of them focus on the possibilities of using external knowledge sources among which prosumers' knowledge seems to become more and more essential (Cui \& Wu, 2015; Geri, Gafni, \& Bengov, 2017; Panni, 2015; Taherparvar et al., 2014).

The authors of this paper, following an extensive review of the literature, did not uncover any deep studies examining, on the one hand, ways in which prosumers share their knowledge with enterprises and public organizations, and, on the other, ways in which enterprises and public organizations expect prosumers to engage in knowledge sharing. Additionally, there were no studies found analyzing the differences and similarities between enterprises and public organizations in the ways they expect prosumers to engage in knowledge sharing. Therefore, it was decided to conduct research among prosumers as well as among enterprises and public organizations. Analyzing enterprises' and public organizations' prosumers-oriented projects may reveal interesting similarities or differences connected with prosumers' and organizations' expectation as to the ways of knowledge sharing. It may help fill in the gap in the existing body of knowledge.

\section{METHODOLOGY}

\section{RESEARCH QUESTIONS}

The main research question: Are the ways in which prosumers share their knowledge with enterprises and public organizations in line with the ways in which enterprises and public organizations expect them to get engaged in knowledge sharing?

To answer the above main research question, the study focuses on addressing the following specific questions:

RQ1: What are the ways in which prosumers of different gender and age share their knowledge with enterprises and public organizations?

\section{To answer this question, two hypotheses are developed:}

H1a: There are statistically significant differences between females and males in the ways in which they share knowledge with enterprises and public organizations.

H1b: There are statistically significant differences between generations of prosumers in the ways in which they share knowledge with enterprises and public organizations.

RQ2: What are the differences and similarities between enterprises and public organizations in the ways they expect prosumers to get engaged in knowledge sharing?

To generate findings on this question, the following hypothesis is developed:

H2: There are statistically significant differences between enterprises and public organizations in the ways they expect prosumers to get engaged in knowledge sharing. 
A research design combining survey study and observation study was adopted in this study.

\section{RESEARCH INSTRUMENT}

To meet the main purpose of this research and answer the specific research questions presented above, it was necessary to collect data from prosumers' and organizations' samples. Therefore, two research instruments were developed:

1. We developed a survey questionnaire to collect empirical data from prosumers. The questionnaire contained a question concerning specified ways of prosumers' knowledge sharing. The question was: What are the ways in which you share your knowledge with enterprises and public organizations? This instrument and the research procedure applied were described in details in another study (Ziemba \& Eisenbardt, 2016).

2. We developed an observational sheet to evidence empirical data from business and public organizations. We employed Microsoft Excel. In the first sheet, definitions and explanations of the main terms used in the spreadsheet were provided, such as prosumer knowledge, prosumer knowledge sharing, and ways of knowledge sharing. In addition, the links to the examples of prosumers' knowledge sharing were stipulated. The second sheet was designed to clarify the research goals and questions. The third sheet was devoted to the description of observed organizations and collection of the data connected with the ways of prosumers' engagement in knowledge sharing.

These instruments allowed us to conduct research among two samples: prosumers and organizations. The study of prosumers helped us answer the first research questions (RQ1), whilst the study of business and public organizations helped us answer the second research questions (RQ2).

\section{DATA COLLECTION}

The data were collected in two stages:

1. The survey's data collection among prosumers took place between December 2014 and March 2015. Using online tools permits contact with an accessible audience as the survey appears on search engine lists due to metatags and appropriate placing of keywords.

2. A non-reactive online observation of enterprises' and public organizations' prosumersoriented projects in which they expect prosumers to engage in knowledge sharing took place in January and February, 2017. The non-reactive online observation means that the observed enterprises and public organizations were not aware of the observation process (Bíró, Botzenhardt, \& Ferdinand, 2014). It was observed whether prosumers shared their knowledge in the ways as expected by the enterprises and public organizations, without any researchers' intervention or direct participation. This research method was employed due to its advantages, i.e. efficiency through available data, openness through anonymity, and authenticity of data sources - not created primarily for research aims (Bíró et al., 2014). The observations were carried out by $10 \mathrm{PhD}$ students under the authors' strict supervision. The students were given training on online observations by authors and the sample case studies were elaborated. Each student involved had to report his or her case studies to the authors. The authors carried out random checks on an ongoing basis. Finally, more than 100 case studies related to prosumers' knowledge sharing with organizations were evidenced in Microsoft Excel. When the collection process was finished, all of the case studies were verified and analyzed by authors for a second time as a final sample. 


\section{SAMPLES}

The designed prosumers' sample size was 2.500 people, comprising people of different age, gender, and ICT skills. The prosumers varied as to their characteristics such as gender and age (taken into further considerations), as well as level of education and place of residence (not taken into further considerations). After screening responses and excluding outliers, there was a final research sample of 783 usable, correct and complete questionnaires. Therefore, the final response rate was $24.44 \%$. However, only 388 questionnaires were analyzed in this study based on the respondents' confirmation of their knowledge sharing with organizations. Cronbach's coefficient alpha was used to perform reliability analysis. For all the analyzed items Cronbach's alpha was 0.881 . Thus, according to Hinton (2004), it can be concluded that the scale had high reliability, and it could be used in the research process.

The sample of observed organizations consisted of enterprises and public organizations. They varied as to their business profile. The gathered 100 case studies were verified and analyzed. After screening the case studies and excluding outliers, there was a final sample of 90 usable, correct, and complete case studies. They included 67 business and 23 public organizations. The enterprises mainly represented banking, clothing, entertaining, IT, toys, press, food, furniture, and jewelry sectors. The public organizations mainly included city halls, schools, and public culture centers.

The final research samples consisted of 388 prosumers and 90 organizations. The descriptives of the research samples are presented in Table 1.

Table 1. Analysis of the research samples

\begin{tabular}{|l|r|r|}
\hline \multicolumn{1}{|c|}{ PROSUMERS } & $\begin{array}{c}\text { Number of } \\
\text { respondents }\end{array}$ & Percentage \\
\hline Gender & 267 & $68.8 \%$ \\
\hline females & 121 & $31.2 \%$ \\
\hline males & & \\
\hline Age & 25 & $6.4 \%$ \\
\hline Builders \& Baby-Boomers (B-B) generations: +50 & 64 & $16.5 \%$ \\
\hline X generation: 36-50 years old & 179 & $46.1 \%$ \\
\hline Y generation: 21-35 years old & 120 & $30.9 \%$ \\
\hline Z generation: less than 21 years old & $\begin{aligned} \text { Number of } \\
\text { organizations }\end{aligned}$ & Percentage \\
\hline ORGANIZATIONS & 67 & $74.4 \%$ \\
\hline Enterprises & 23 & $25.6 \%$ \\
\hline Public organizations & & \\
\hline
\end{tabular}

\section{DATA ANALYSIS}

The data were stored in Microsoft Excel format. Using Microsoft Excel, PS IMAGO (formerly SPSS), Statistica package, the collected data were analyzed in the following stages:

1. To generate findings on the first question (RQ1), two hypotheses were developed:

H1a: There are statistically significant differences between females and males in the ways in which they share knowledge with enterprises and public organizations.

H1b: There are statistically significant differences between generations of prosumers in the ways in which they share knowledge with enterprises and public organizations. 
Since we used convenient samples in the study, non-parametric statistical tests, Mann-Whitney U-Test and Kruskal-Wallis one-way analysis of variance, were used to determine whether the two hypotheses (H1a and $\mathrm{H} 1 \mathrm{~b}$ ) were supported by our empirical data. In addition, the descriptive statistics such as mean, median, mode and standard deviation were employed to assess the ways in which prosumers share knowledge with enterprises and public organizations.

2. To generate findings on the second question (RQ2), the following hypothesis was developed:

$\mathrm{H} 2$ : There are statistically significant differences between enterprises and public organizations in the ways they expect prosumers to get engaged in knowledge sharing.

Since we used convenient samples in the study, a $\mathrm{Chi}=$ Square test was used to determine whether the $\mathrm{H} 2$ hypothesis was supported by our empirical data. In addition, the descriptive statistics such as mean, median, mode and standard deviation were employed to assess the ways in which prosumers share knowledge with enterprises and public organizations. In addition, the percentages were employed to assess how many examined enterprises and public organizations use the different ways in which prosumers share knowledge.

\section{FINDINGS}

\section{THE WAYS IN WHICH PROSUMERS SHARE THEIR KNOWLEDGE - GENERAL ANALYSIS}

As the first attempt to answer the first research question (RQ1), the descriptive data analysis results are presented in Table 2.

Table 2. Descriptive statistics for ways in which prosumers share their knowledge

\begin{tabular}{|l|c|c|c|c|}
\hline \multicolumn{1}{|c|}{$\begin{array}{c}\text { Ways in which prosumers share their } \\
\text { knowledge }\end{array}$} & Mean & Median & Mode & $\begin{array}{c}\text { Standard } \\
\text { deviation }\end{array}$ \\
\hline Evaluating products by scoring & 4.11 & 4 & 4 & 0.99 \\
\hline Evaluating products by comments & 3.80 & 4 & 4 & 1.15 \\
\hline Creating and designing products or their parts & 2.41 & 2 & 2 & 1.25 \\
\hline
\end{tabular}

The results presented in Table 2 show that prosumers share their knowledge mainly by evaluating products by scoring (mean $=4.11$; median $=4$; and mode $=4$ ) and by evaluating products by comments $($ mean $=3.80$; median $=4$; and mode $=4$ ). The mode values in both cases are equal to 4 , showing that the majority of prosumers indicated that they would rather share knowledge in these ways. Different situation pertains to creating and designing products or their parts (mean=2.41; median $=2$; and mode $=2$ ). The mean, median, and mode values are low indicating that prosumers were rather reluctant as to that way of knowledge sharing.

The results presented above are general - they embrace all prosumers regardless their characteristics. It was decided to perform detailed analyses for respective groups of prosumers. It can help enterprises and public organizations answer the question in which ways are prosumers willing to share knowledge accounting for their gender and age.

\section{THE WAYS IN WHICH PROSUMERS SHARE THEIR KNOWLEDGE REGARDING THEIR GENDER}

To test H1a in order to answer the research question RQ1, the Mann-Whitney U test was conducted for gender group comparison. The test results presented in Table 3 show that just in case of creating and designing products or their parts the $p$ value is lower than 0.05 . It means that there were significant 
differences between females and males in case of creating and designing products or their parts. The test did not show any significant differences between genders in case of evaluating products by scoring or by comments. Thus, hypothesis H1a is partially supported in our study.

Table 3. The Mann-Whitney $U$ test results for females and males in ways which they share knowledge. Source: own elaboration

\begin{tabular}{|l|c|c|c|c|}
\hline \multicolumn{1}{|c|}{$\begin{array}{c}\text { Ways in which prosumers share their } \\
\text { knowledge }\end{array}$} & females & males & $\mathbf{Z}$ & p-value \\
\hline Evaluating products by scoring & 267 & 121 & -0.308 & 0.757 \\
\hline Evaluating products by comments & 267 & 121 & 0.945 & 0.344 \\
\hline Creating and designing products or their parts & 267 & 121 & 2.080 & 0.037 \\
\hline
\end{tabular}

The Mann-Whitney $U$ test shows that there were significant differences between females and males only in case of creating and designing products or their parts. Nonetheless, we decided to perform detailed analysis of the ways in which females and males share knowledge as our intention was to draw a whole picture of the ways females and males share their knowledge. The analysis was made using box plots. The results are presented in Figure 3.

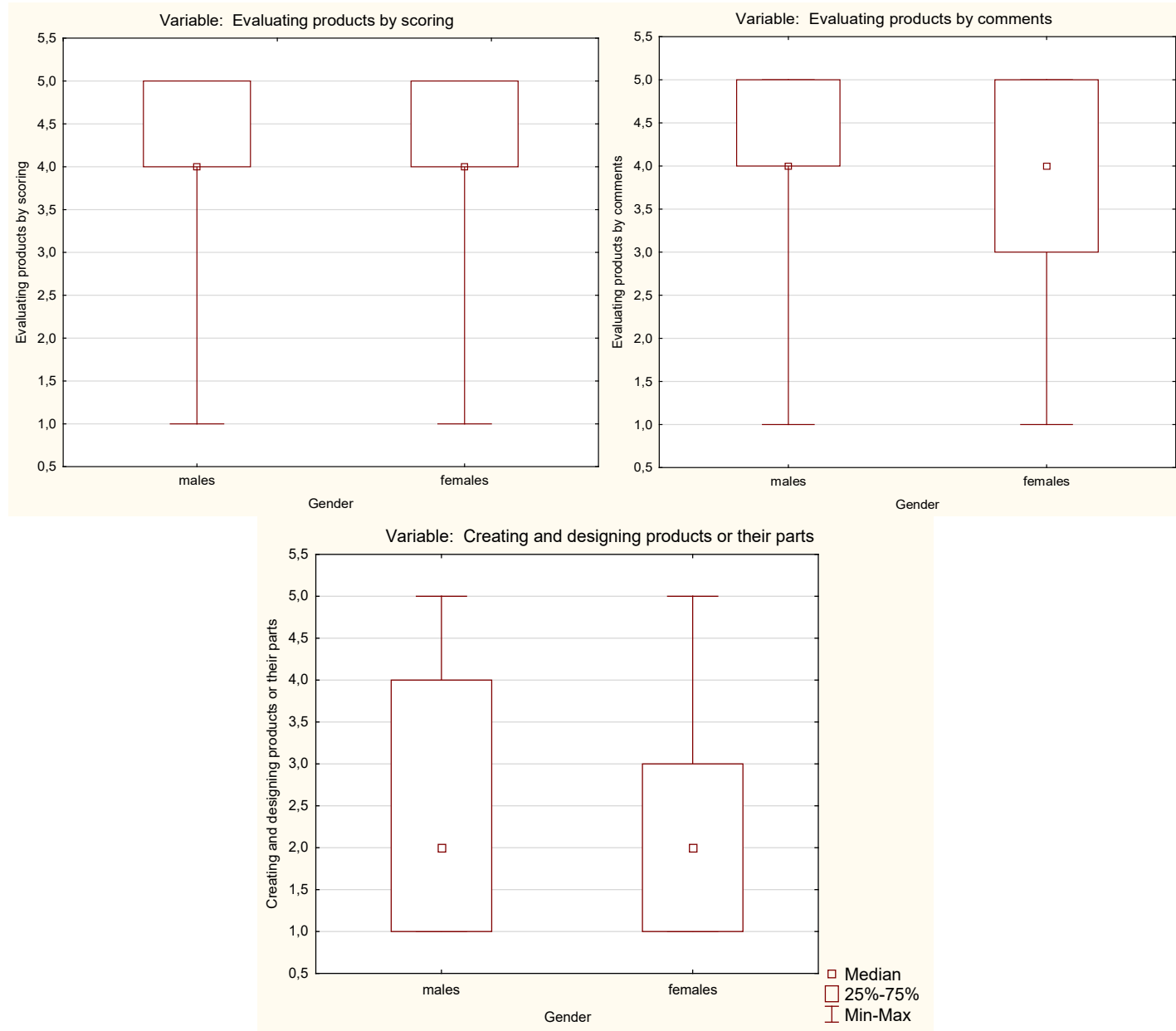

Figure 3. The Ways of Females' and Males' Knowledge Sharing. 
The detailed analysis presented in Figure 3 confirms that there were no median differences between females and males. Nonetheless, it shows that the greatest differences between females and males pertain to:

- first quartile (Q1: 25\%) in case of evaluating products by comments, indicating that males are more willing to share their knowledge by comments (Q1=4 for males whilst for females Q1=3). What is more, most males indicated 4 or 5 , so they rather or often are evaluating products by comments, whilst females indicated from 3 to 5 . It means that there is a group of females who have no opinion in that case, indicating 3 ; and

- third quartile (Q3: 75\%) in case of creating and designing products or their parts indicates that males are more willing than females to share knowledge by creating and designing products or their parts. Regardless the median values are equal for males and females, the Q3=4 for males, whilst for females Q3=3. It means that males are more willing to share knowledge in that way as compared to the females.

\section{THE WAYS IN WHICH PROSUMERS SHARE THEIR KNOWLEDGE REGARDING THEIR AGE}

To test H1b and in order to answer the research question RQ1, the Kruskal-Wallis one-way analysis of variance was used as there were four independent generation groups under study: Builders \& Baby-boomers (B-B) generations combined (25 of prosumers), X generation (64 of prosumers), Y generation (179 of prosumers), and $\mathrm{Z}$ generation (120 of prosumers). The test results presented in Table 4 show that there were no significant differences between the generation groups in ways of their knowledge sharing. Thus, the hypothesis H1b was rejected.

Table 4. Kruskal-Wallis analysis of results for generations of prosumers in the ways in which they share knowledge

\begin{tabular}{|l|c|c|c|}
\hline \multicolumn{1}{|c|}{$\begin{array}{c}\text { Ways in which prosumers share their } \\
\text { knowledge }\end{array}$} & $\chi^{\mathbf{2}}$ & df & p-value \\
\hline Evaluating products by scoring & 1.003 & 3 & 0.800 \\
\hline Evaluating products by comments & 0.328 & 3 & 0.955 \\
\hline Creating and designing products or their parts & 1.679 & 3 & 0.642 \\
\hline
\end{tabular}

Regardless of the Kruskal-Wallis analysis results, it was decided to perform detailed analysis for each way of knowledge sharing as our intention was to draw a whole picture of the ways in which respective generations of prosumers share their knowledge. The analysis was made using box plots. The results are presented in Figure 4. 

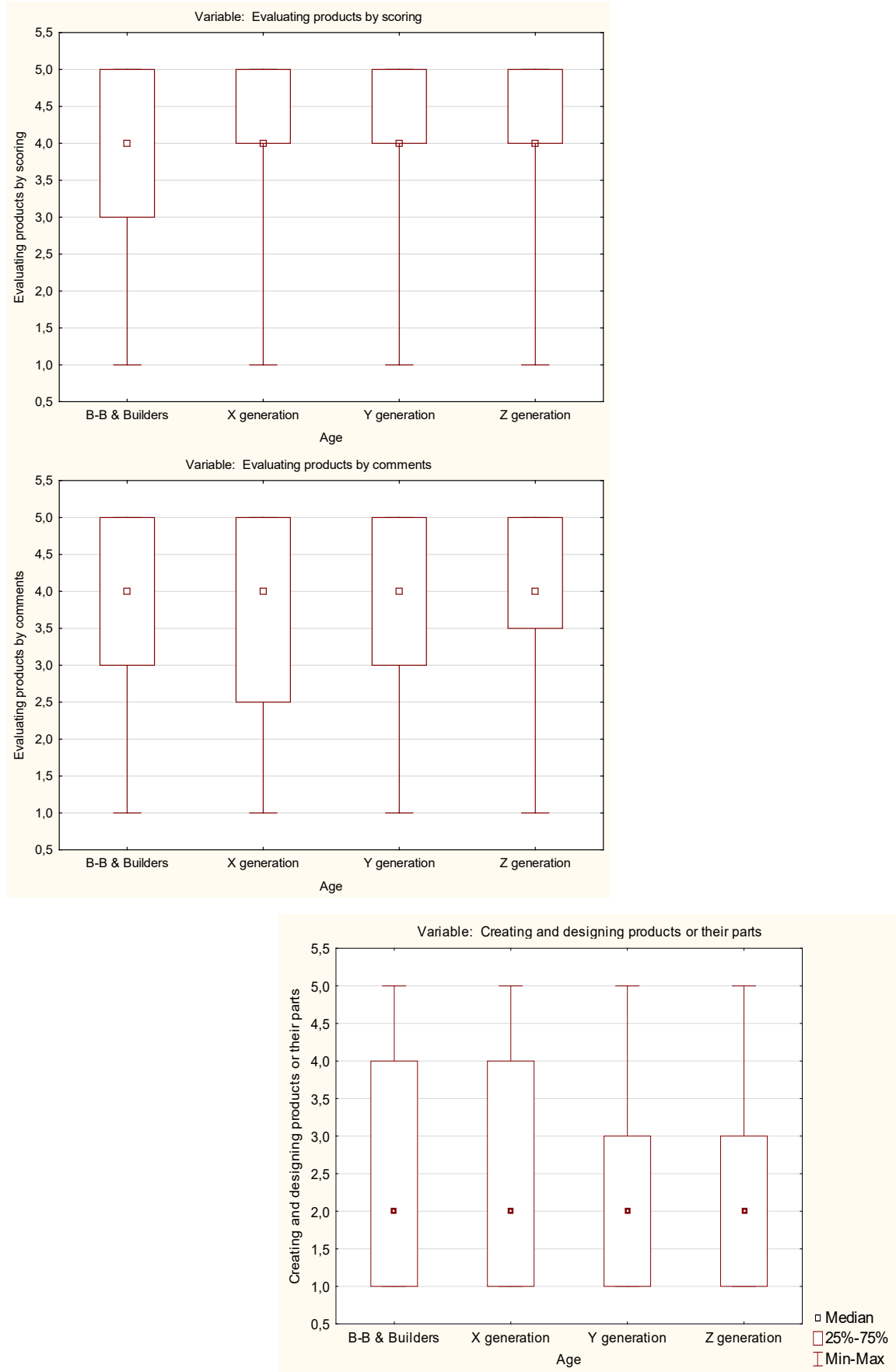

Figure 4. Ways of Knowledge Sharing by Respective Prosumers' Generations.

The detailed analysis presented in Figure 4 confirms that there were no median differences between generations of prosumers. The median values for evaluating products by scoring and evaluating products by comments are 4 , indicating that, regardless of the generation, prosumers rather share knowledge in these ways. On the other hand, for creating and designing products or their parts the median value is 2 , indicating that prosumers are rather reluctant to share knowledge in that way. What is more, it is easy to notice, that most prosumers indicated from 3 to 5 in case of evaluating products by scoring and evaluating products by comments, what means that they are active knowledge creators in these ways. Nonetheless, they indicated from 3 to 1 in case of creating and designing products or their parts. It means that prosumers far more rarely share their knowledge in that way. It worth to 
stress, that younger generations ( $\mathrm{Z}$ and $\mathrm{Y})$ are less willing to share their knowledge by creating and designing products or their parts than the oldest ones (X and Baby-Boomers(B-B) \& Builders combined). It is shown in the third box plot.

\section{THE WAYS IN WHICH ENTERPRISES AND PUBLIC ORGANIZATIONS EXPECT TO ENGAGE PROSUMERS IN KNOWLEDGE SHARING}

To test $\mathbf{H} \mathbf{2}$ and in order to answer the research question RQ2, the Chi-Square test was used as there were two groups (fractions) under the study: 67 of enterprises and 23 of public organizations, and two categories: expecting and not expecting prosumers to get engaged in knowledge sharing. The test results presented in Table 5 show that the differences between enterprises and public organizations are not statistically significant. Thus, the hypothesis $\mathbf{H} \mathbf{2}$ was rejected.

Table 5. Chi-Square analysis of results for enterprises and public organizations in the expectations to get prosumers engaged in knowledge sharing

\begin{tabular}{|l|c|c|}
\hline & $\mathbf{C h i}^{\mathbf{2}}$ & p-value \\
\hline Evaluating products by scoring & 1.506 & 0.220 \\
\hline Evaluating products by comments & 1.775 & 0.183 \\
\hline Creating and designing products or their parts & 0.267 & 0.605 \\
\hline
\end{tabular}

Regardless of the Chi-Square analysis results, it was decided to perform a detailed analysis for each way of knowledge sharing as our intention was to draw a whole picture of enterprises' and public organizations' expectations to get prosumers engaged in knowledge sharing. The analysis was made using frequency procedures. The results are presented in Figure 5.

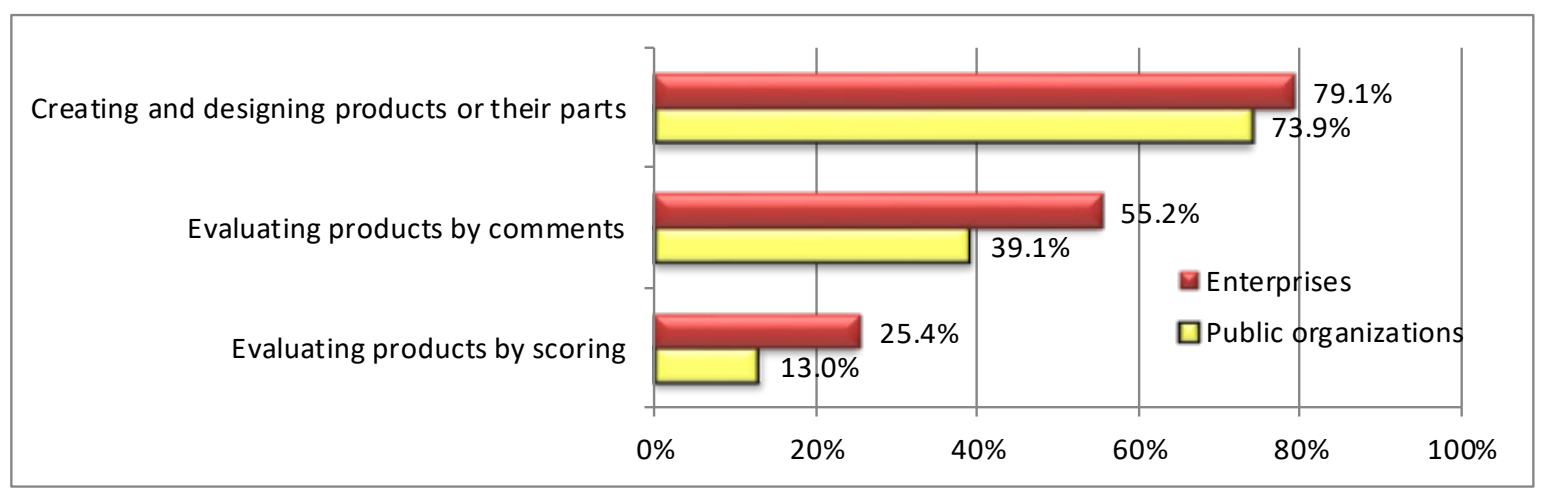

Figure 5. Enterprises and Public Organizations Expectations for Prosumers Knowledge Sharing.

The results presented in Figure 5 show that enterprises expect to engage prosumers in knowledge sharing in each available way more often than public organizations do it. Thus, it is possible to draw a conclusion that enterprises, by offering prosumers more possibilities of commenting on products, can expect more prosumers' comments and in turn can gather more prosumers' knowledge than public organizations. Additionally, the outcomes show that both types of organizations primarily expect prosumers to engage in knowledge sharing by creating and designing products. In turn, one can draw a conclusion that both - enterprises and public organizations target their projects at this way of prosumers' knowledge sharing because it enables them to obtain a valuable knowledge which could be utilized for product improvement and development. In general, the results show that most of enterprises and public organizations expect prosumers to engage in knowledge sharing by creating 
and designing products or their parts (50 enterprises and 17 public organizations) while they seldom expect them to engage in products' evaluation by scoring (16 enterprises and 3 public organizations).

\section{DISCUSSIONS AND CONCLUSIONS}

\section{CONTRIBUTIONS}

This work represents one of the few empirical studies on consumer's knowledge sharing and cocreating unique value with customers. It contributes to the existing research on such issues by indicating:

- ways in which consumers called prosumers share knowledge with business and public organizations; and

- ways in which enterprises and public organizations expect consumers called prosumers to get engaged in knowledge sharing.

There are three ways in which prosumers can share their knowledge with business and public administration: (1) evaluating products by scoring, (2) evaluating products by comments, and (3) creating and designing products. Having investigated those ways, we may conclude that prosumers in our study share their knowledge mainly by evaluating products with usage of scoring and comments, whereas they create and design products very rarely.

Analyzing the ways in which examined prosumers of different gender and age share their knowledge with enterprises and public organizations it may be concluded that there are no significant statistical differences between males and females in case of evaluating products by scoring and comments. Such differences are identified for creating and designing products, i.e. males are more willing to share knowledge by creating and designing products than females. In addition, regarding age of prosumers, there are no significant statistical differences in ways in which prosumers in our study share their knowledge with business and public organizations. The results revealed partial support for one of the formulated hypothesis (H1a) and one hypothesis (H1b) was not supported (Table 6).

\section{Table 6. Summary of hypotheses tests}

\begin{tabular}{|l|l|}
\hline \multicolumn{1}{|c|}{ Hypothesis } & \multicolumn{1}{|c|}{ Findings } \\
\hline $\begin{array}{l}\text { H1a: There are statistically significant differences between females and males in the } \\
\text { ways in which they share knowledge with enterprises and public organizations. }\end{array}$ & $\begin{array}{l}\text { Supported } \\
\text { partially }\end{array}$ \\
\hline $\begin{array}{l}\text { H1b: There are statistically significant differences between generations of prosumers } \\
\text { in the ways in which they share knowledge with enterprises and public organizations. }\end{array}$ & $\begin{array}{l}\text { Not } \\
\text { supported }\end{array}$ \\
\hline $\begin{array}{l}\text { H2: } \text { There are statistically significant differences between enterprises and public or- } \\
\text { ganizations in the ways they expect prosumers to get engaged in knowledge sharing. }\end{array}$ & $\begin{array}{l}\text { Not } \\
\text { supported }\end{array}$ \\
\hline
\end{tabular}

Analyzing the ways in which organizations expect prosumers to engage in knowledge sharing, we observe that most of enterprises and public organizations under study expect prosumers to engage in knowledge sharing by creating and designing products. Prosumers are less frequently engaged by organizations in products' evaluation by comments and they are seldom engaged in products' evaluation by scoring. In addition, enterprises more often engage prosumers in knowledge sharing than public organizations. The analysis shows that the differences between examined enterprises and public organizations are not statistically significant. Thus, the third hypothesis (H2) was not supported (Table 6).

In summary, our research among two samples: prosumers and organizations allow us to indicate whether the ways in which prosumers share their knowledge with enterprises and public 
organizations are in line with the ways in which enterprises and public organizations expect them to get engaged in knowledge sharing. However, such a conclusion arises from a qualitative comparison of the obtained results as well as from logical reasoning. Based on the examination of prosumers, it has been found that the average levels of prosumers' knowledge sharing ranged from 2.41 to 4.11 (on a 5-point scale from 1.00 to 5.00). Median values were in the range between 2.00 and 4.00. On average, the level of evaluating products by scoring was the highest (4.11), followed by evaluating products by comments (3.80). The level of creating and designing products or their parts was the lowest (2.41). Meanwhile, the results of examining organizations revealed that most of enterprises (79.1\%) and public organizations $(73.9 \%)$ expect prosumers to engage in knowledge sharing by creating and designing products or their parts while they seldom expect them to engage in products' evaluation by scoring, respectively $25.4 \%$ and $13.0 \%$. Based on these findings, it can be stated that there are differences between the ways in which prosumers in our study expect to share knowledge with organizations and the ways in which the organizations under study expect prosumers to get engaged in knowledge sharing. Prosumers mainly share their knowledge with organizations by evaluating products - using scoring and comments, whereas organizations mainly expect prosumers to engage in knowledge sharing by creating and designing products.

The greatest benefits and value for organization could be the result of engaging prosumers in creating and designing products. In that way prosumers may share their knowledge about already existing products, and improve products' functionality, reliability, or convenience of use, very often thinking in an extraordinary, outside the box way. Thus, the enterprise can obtain a lot of prosumers' knowledge on products which could lead to the development and improvement of products. On the other hand, prosumers can be engaged in co-creation of new products and have an impact on the look, design, functionality, and usability of products. This kind of prosumers' knowledge can have the biggest value for enterprises.

However, the research findings show that prosumers are not interested in knowledge sharing by creating and designing products. They evaluate products by scoring and comments more often. It means that organizations should make prosumers fully aware of their benefits from knowledge sharing by creating and designing products, e.g. product adjustment to their expectations. It is necessary for organizations to deliver different kinds of incentives to prosumers for encouraging them to be value creators, not only feedback providers.

With regard to the presented results, it is reasonable to conclude that this study expands the existing studies on consumer's knowledge sharing and co-creating unique value with customers. None of the previous studies fully reported ways in which prosumers can share knowledge with enterprises and public organizations (e.g., Aghamirian et al., 2013, 2015; Choi \& Shah, 2014; Cui \& Wu, 2015; Prahalad \& Ramaswamy, 2004; Trejo et al., 2016). This study is complementary with findings related to paramount issues for prosumers' knowledge utilization in organizations presented in Figure 1, i.e. incentives encouraging consumers to engage in knowledge sharing, ICT supporting consumers' knowledge sharing, and business processes in which consumers' knowledge can be used.

A major challenge for organizations involves motivating prosumers to share their knowledge. This problem is addressed by incentives encouraging prosumers to engage in knowledge sharing (Ho \& Kuo, 2013; Löcker et al., 2014; Ziemba \& Eisenbardt, 2014). Ziemba, Eisenbardt, Mullins, and Grabara (2017) proposed model in which a distinction between tangible and intangible incentives was made. The tangible incentives include direct financial incentives (e.g. monetary compensation) and indirect financial incentives (e.g. premiums in the form of free products, bonus points with financial value), whereas the named intangible incentives are categorized into four groups: activity incentives, social incentives, tool-related incentives, and promotion-related incentives. Overall, their research findings among Polish and UK-based prosumers show that the considerable number of prosumers needs incentives to share knowledge. Furthermore, tangible incentives are particularly encouraging them to share knowledge. 
The second paramount issue for prosumers' knowledge utilization is ICT. They can enhance the knowledge sharing by lowering temporal and spatial barriers between prosumers and organizations, and supporting consumers' knowledge sharing (Bayram \& Demirtel, 2014; Jiebing et al., 2013; Ritzer \& Jurgenson, 2010). Ziemba, Eisenbardt, \& Mullins (2017) examined the usage of ICT by Polish and UK-based prosumers. It is found that prosumers for knowledge sharing mainly use enterprises' websites, e-mails, Internet forums, Facebook fanpages, mobile applications, and online surveys. Other ICT were used by prosumers but very rarely. The mobile applications being favored amongst the UK respondents whereas the dedicated enterprise website is the favored ICT amongst Polish respondents.

The last component of the model of using prosumers' knowledge in enterprises is business processes in which consumers' knowledge can be used (Gibbert et al., 2002; Prahalad \& Ramaswamy, 2004). Ziemba \& Eisenbardt (2015) adopted APQC Process Classification Framework to propose a conceptual framework of prosumers' participation in business processes. The study amongst Polish prosumers indicated that prosumers actively participate in two processes: Develop and manage products and services and Market and sell products and services.

\section{IMPLICATIONS FOR RESEARCH AND PRACTICE}

The novel empirically validated findings provide theoretical and practical insights into designing mechanisms for increasing prosumers' engagement in knowledge sharing with business and public organizations for co-creating values. Further, the findings of the study confirm the need for more empirical and in-depth investigations to reconfirm them in others samples.

The design and implementation of effective prosumer knowledge utilization in enterprises are challenging for researchers. To tackle this challenge, they may use this methodology and do similar analyses with different sample groups in Poland and other countries, and many comparisons between different groups and countries can be made. Their goal could be also to focus on the analysis of ways of knowledge sharing with the aim of adjusting such ways to the expectations of prosumers. Although, the methodology constitutes a very comprehensive basis for identifying how organizations may utilize prosumers' knowledge in general for improving their products, researchers may develop, verify and improve this methodology and its implementation.

Besides, practitioners are encouraged to evaluate the ways of prosumers' knowledge sharing to take an advantage of prosumers' knowledge. The findings of this study will aid organizations in making decisions for more progressive and effective activities aimed at prosumers' knowledge utilization, especially helping them understand ways of prosumers' knowledge sharing and adjust those ways to prosumers' expectations.

\section{LIMITATIONS AND FURTHER RESEARCH}

As with many other studies, this one also has its limitations. The first one was the selection of the survey respondents and case studies. They are related to the Polish market. Therefore, it is advisable to extend the research field to the respondents and case studies from other countries - less and better developed in the meaning of prosumers' engagement. To achieve that we would like to perform detailed companies' analysis in the range of prosumers engagement.

The second limitation relates to the fact that prosumers' knowledge sharing and prosumers' knowledge utilization by enterprises and public organizations are new phenomena that are thriving and evolving continuously. This creates opportunities for conducting further interesting research and setting research challenges for the future. Therefore, the longitudinal study of these phenomena is needed. 
Findings from this study suggest many opportunities for future exploration in this field. Among the many possibilities, online observations of other markets as well as in-depth interviews and survey questionnaires with enterprises and public organizations seem most interesting and promising.

\section{REFERENCES}

Aghamirian, B., Dorri, B., \& Aghamirian, B. (2013). Effects of customer knowledge management's eight factors in e-commerce. Management Science and Engineering, 7(4), 1-11.

Aghamirian, B., Dorri, B., \& Aghamirian, B. (2015). Customer knowledge management application in gaining organization's competitive advantage in electronic commerce. Journal of Theoretical and Applied Electronic Commerce Research, 10(1), 63-78. https://doi.org/10.4067/S0718-18762015000100006

Barger, V., Peltier, J. W., \& Schultz, D. E. (2016). Social media and consumer engagement: A review and research agenda. Journal of Research in Interactive Marketing, 10(4), 268-287. https://doi.org/10.1108/JRIM-06$\underline{2016-0065}$

Bayram, Ö. G., \& Demirtel, H. (2014). Effect of ICT on information sharing in enterprises: The case of Ministry of Development. In: Proceedings of European Conference on Knowledge Management ECKM. Kidmore End: Academic Conferences International Limited, 94-101.

Bíró S., Botzenhardt, F., \& Ferdinand, H. M. (2014). Online surveys vs. online observations: A comparative analysis of online research methods and their impact on brand management. Markenbrand, 2, 49-56.

Brabham, D. C. (2012). Motivations for participation in a crowdsourcing application to improve public engagement in transit planning. Journal of Applied Communication Research, 40(3), 307-328. https://doi.org/10.1080/00909882.2012.693940

Bryant, C. A. (2011). The social media bubble: An examination of social media user motivations and their implications for future users and communication technologies, Paper 161. University Carbondale, Southern Illinois. Retrieved from http://opensiuc.lib.siu.edu/gs rp/161

Calosci, A. (2017). Places, communities and knowledge. You'll be part of an upcoming exhibition. The Design Journal, 20(1), S3393-S3400. https://doi.org/10.1080/14606925.2017.1352843

Cheng, M. Y., Ho, J. S. Y., \& Lau, P. M. (2009). Knowledge sharing in academic institutions: A study of multimedia university Malaysia. Electronic Journal of Knowledge Management, 3(7), 313-324.

Choi, D., \& Shah, C. (2014). Perceived value of information sharing in online environments: User engagement and social reputation. The Information Association for the Information Age ASIS \&T 2014 Annual Meeting. https://doi.org/10.1002/meet.2014.14505101052

Croteau, A.-M., \& Li, P. (2003). Critical success factors of CRM technological initiatives. Canadian Journal of Administrative Sciences, 20(1), 21-34. https://doi.org/10.1111/j.1936-4490.2003.tb00303.x

Cui, A. S., \& Wu, F. (2015). Utilizing customer knowledge in innovation: Antecedents and impact of customer involvement on new product performance. Journal of the Academy of Marketing Science, March, 1-23. https://doi.org/10.1007/s11747-015-0433-x

Ford, D. P., \& Mason, R. M. (2013). A multilevel perspective of tensions between knowledge management and social media. Journal of Organizational Computing and Electronic Commerce, 23(1-2), 7-33. https://doi.org/10.1080/10919392.2013.748604

Fuchs, C. (2017). Social media: A critical introduction. London: SAGE Publications Ltd.

Gafni, R., Geri, N., \& Bengov, P. (2014). Investigating the effect of tangible and virtual rewards on knowledge contribution in online communities. Online Journal of Applied Knowledge Management, 2(2), 1-11.

Gafni, R., \& Golan, O. T. (2016). The influence of negative consumer reviews in social networks. Online Journal of Applied Knowledge Management, 4(2), 44-58.

Geri, N., Gafni, R., \& Bengov, P. (2017). Crowdsourcing as a business model: extrinsic motivations for knowledge sharing in user-generated content websites. Journal of Global Operations and Strategic Sourcing 10(1), 90-111. https://doi.org/10.1108/JGOSS-05-2016-0018 
Gibbert, M., Leibold, M., \& Probst, G. (2002). Five styles of customer knowledge management, and how smart companies use them to create value. European Management Journal, 20(5), 459-469. https://doi.org/10.1016/S0263-2373(02)00101-9

Goh, K.-Y., Heng, C.-S., \& Lin, Z. (2013). Social media brand community and consumer behavior: Quantifying the relative impact of user- and marketer-generated content. Information Systems Research, 24(1), 88-107. https://doi.org/10.1287/isre.1120.0469

Hinton, P. R., Brownlow, C., \& McMurvay, I., \& Cozens, B. (2004). SPSS Explained. East Sussex: Routledge.

Ho, L-A., \& Kuo, T-H. (2013). How system quality and incentive affect knowledge sharing. Industrial Management \& Data Systems, 113(7), 1048-1063. https://doi.org/10.1108/IMDS-01-2013-0015

Jelonek, D. (2013). Prosumption in creating value for the customer. Proceedings of International Scientific Conference: Business Management - Practice and Theory in the 21st Century, 6-7 June 2013. Nitra, Slovakia, 262-271.

Jiebing, W., Bin, G., \& Yongjiang, S. (2013). Customer knowledge management and IT-enabled business model innovation: A conceptual framework and a case study from China. European Management Journal, 31(4), 359372. https://doi.org/10.1016/j.emj.2013.02.001

Katemukda, N., \& Sudasna-Na-Ayudthya, P. (2015). The success of product and process innovation generated from customer knowledge management. Proceedings of the 12th International Conference on Intellectual Capital, Knowledge Management and Organisational Learning, ICICKM, 5-6 November, 2015, 125-132.

Kettles, D., St. Louis, R. D., \& Steinbart, P. J. (2017). An experimental investigation of the individual and joint effects of financial and non-financial incentives on knowledge sharing using enterprise social media. Communications of the Association for Information Systems, 41, Art.27. doi: 10.17705/1CAIS.04127

Lichtenthaler, U. (2017). Shared value innovation: Linking competitiveness and societal goals in the context of digital transformation. International Journal of Innovation and Technology Management, 14(4). https://doi.org/10.1142/S0219877017500183

Löcker, A. K., Eraßme, D., Jakobs, E. M., Schaar, A. K., Valdez, A. C., \& Ziefle, M. (2014). Yet another platform? Motivational factors for using online communities in business contexts. In Proceedings of the 5 th International Conference on Applied Human Factors and Ergonomics AHFE 2014, July 19-23, 2014, Krakow, Poland, 1145-1156.

Ma, W. W. K., \& Yuen, A. H. K. (2011). Gender differences of knowledge sharing in online learning environment. In R. Kwan (Ed.), Proceeding ICHL'11 Proceedings of the 4th International Conference on Hybrid Learning Pages, 116-128. Berlin Heidelberg: Springer-Verlag. https://doi.org/10.1007/978-3-642-22763-9 11

McCrindle, M. (2014). The ABC of XYZ. Understanding the global generations. Bella Vista: McCrindle Research Pty.

Mitręga, M. (2013). Czy prosumpcja w dobie kryzysu to zjawisko jednowymiarowe? Eksploracja wśród użytkowników portali społecznościowych [In times of crisis, if prosumption is an one-dimensional phenomenon? Exploration of social networks members]. Problemy Zarzadzania, 1(40), 40-53. https://doi.org/10.7172/1644-9584.40.3

Nonaka, I., \& Takeuchi, H. (2000). Kreowanie wiedsy w organizacji [Knowledge creation in organizations]. Warsaw: Poltext Press.

Omotayo, F. O. (2015). Knowledge management as an important tool in organisational management: A review of literature. Library Philosophy and Practice, 1238 [e-journal]. Retrieved from http://digitalcommons.unl.edu/libphilprac/1238

Panni, M. F. A. K. (2015). CKM and its influence on organizational marketing performance: Proposing an integrated conceptual framework. In H. R. Kaufman \& M. F. A. K. Panni (Eds.), Customer-centric marketing strategies: Tools for building organizational performance. Hershey: IGI Global, 103-125. https://doi.org/10.4018/978-1-4666-2524-2.ch006

Prahalad, C. K., \& Ramaswamy, V. (2004). The future of competition. Co-creating unique value with customers. Boston: Harvard Business School Press. 
The Ways of Prosumers' Knowledge Sharing with Organizations

Rayna, T., \& Striukova, L. (2016). Involving consumers: The role of digital technologies in promoting 'prosumption' and user innovation. Journal of the Knowledge Economy, 1-20. https://doi.org/10.1007/s13132$\underline{016-0390-8}$

Ritzer, G. (2015). The dehumanized consumer: Does the prosumer offer some hope? In A. N. García Martínez (Ed.), Being buman in a consumer society (pp. 25-40). New York: Ashgate.

Ritzer, G., \& Jurgenson, N. (2010). Production, consumption, prosumption: The nature of capitalism in the age of the digital 'prosumer'. Journal of Consumer Culture, 10(1), 13-36. https://doi.org/10.1177/1469540509354673

Shihab, M. R., \& Lestari, A. A. (2014). The impact of customer knowledge acquisition to knowledge management benefits: A case study in Indonesian banking and insurance industries. Proceedings of 2014 International Conference on Advanced Computer Science and Information Systems, 301-306. https://doi.org/10.1109/ICACSIS.2014.7065867

Song, E.-J., \& Kang, M.-S. (2016). A study on the platform of knowledge integration for customer feedback in B2C service industry. International Journal of Information and Communication Technology, 8(1), 26-36. https://doi.org/10.1504/IJICT.2016.073637

Taherparvar, N., Esmaeilpour, R., \& Dostar, M. (2014). Customer knowledge management, innovation capability, and business performance: A case study of the banking industry. Journal of Knowledge Management, 3(18), 591-610. https://doi.org/10.1108/JKM-11-2013-0446

Toffler, A. (1980). The third wave. New York: Bantam Books.

Trejo, J. M., Gutiérrez, J. S., \& Guzman, G. M. (2016). The customer knowledge management and innovation. Contaduría y Administración, 61(3), 456-477. https://doi.org/10.1016/i.cya.2015.11.011

Tsai, W., Tsai, M., Li, S., \& Lin, C. (2012). Harmonizing firms' knowledge and strategies with organizational capabilities. Journal of Computer Information Systems, 53(1), 23-32.

Tseng, S.-M. (2016). The effect of knowledge management capability and customer knowledge gaps on corporate performance. Journal of Enterprise Information Management, 29(1). https://doi.org/10.1108/JEIM-03$\underline{2015-0021}$

Vashisht, D., \& Pillai, S. S. (2017). Are you able to recall the brand? The impact of brand prominence, game involvement and persuasion knowledge in online - Advergames. Journal of Product \& Brand Management, 26(4), 402-414. https://doi.org/10.1108/JPBM-02-2015-0811

Xie, C., Bagozzi, R. P., \& Troye, S. V. (2008). Trying to prosume: Toward a theory of consumers as co-creators of value. Journal of the Academy of Marketing Science, 36, 109-122. https://doi.org/10.1007/s11747-007$\underline{0060-2}$

Yang, X., \& Li, G. (2016). Factors influencing the popularity of customer-generated content in a companyhosted online co-creation community: A social capital perspective. Computers in Human Behaviour, 64, 760768. https://doi.org/10.1016/i.chb.2016.08.002

Yuan, D., Lin, Z., \& Zhuo, R. (2016). What drives consumer knowledge sharing in online travel communities? Personal attributes or e-service factors?. Computers in Human Behaviour, 63, 68-74. https://doi.org/10.1016/j.chb.2016.05.019

Ziemba, E. (2013). Conceptual model of information technology support for prosumption. Proceedings of International Conference on Management, Leadership and Governance - ICMLG, February 07-08, 2013, Bangkok University, 355-363.

Ziemba, E., \& Eisenbardt, M. (2013). Prosumption awareness among young consumers. Studia Ekonomiczne, 153, 163-177.

Ziemba, E., \& Eisenbardt, M. (2014). Prosumers' eagerness for knowledge sharing with enterprises - A Polish study. Online Journal of Applied Knowledge Management, 2(1), 40-58.

Ziemba, E., \& Eisenbardt, M. (2015). Examining prosumers participation in business processes. Polish Journal of Management Studies, 12(1), 219-229. 
Ziemba, E., \& Eisenbardt, M. (2016). Incentives encouraging prosumers to knowledge sharing - Framework based on Polish study. Online Journal of Applied Knowledge Management, 4(2), 146-166.

Ziemba, E., \& Eisenbardt, M. (2017). Utilization of consumers' knowledge in organizations. In F. Marimon, M. Mas-Machuca, J. Berbegal-Mirabent, \& R. Bastida (Eds.), Proceedings of the 18th European Conference on Knowledge Management ECKM 2017, 2, September 7-8, 2017, International University of Catalonia, Barcelona, Spain, 1084-1093.

Ziemba, E., Eisenbardt M., \& Eisenbardt T. (2016). People in sustainable information society. In E. Ziemba (Ed.), Towards a sustainable information society: People, business and public administration perspectives. Newcastle upon Tyne: Cambridge Scholars Publishing, 73-133.

Ziemba, E., Eisenbardt, M., \& Mullins, R. (2017). Use of information and communication technologies for knowledge sharing by Polish and UK-based prosumers. In E. Ziemba (Ed.), Information Technology for Management: New Ideas and Real Solutions. Lecture Notes in Business Information Processing, (p. 277). Springer, Cham. https://doi.org/10.1007/978-3-319-53076-5 4

Ziemba, E., Eisenbardt, M., Mullins, R., \& Grabara, D. (2017). Investigating incentives that encouraged and can encourage Polish and UK-based prosumers to engage in knowledge sharing. Online Journal of Applied Knowledge Management, 5(1), 72-100.

\section{BIOGRAPHIES}

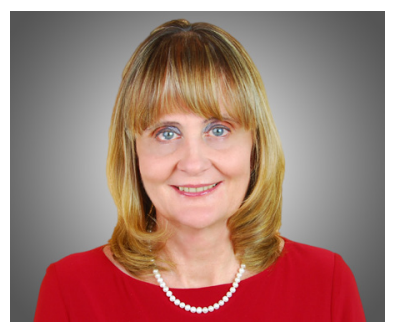

Ewa Ziemba completed her Ph.D. and Post Ph.D. in Management, with a major focus on management information systems. She is an Associate Professor at the University of Economics, Katowice, Poland. Her current research focuses on information systems and technologies for business and public administration transformation. She has published over 170 peer-reviewed papers and 18 books, and has played an instrumental role in prestigious Polish and international research projects. Ewa Ziemba serves on the editorial boards of several international journals, is the Founding Editor-in-Chief of The Online Journal of Applied Knowledge Management, the Editor-in-Chief of Journal of Economics and Management, and the Editor of Interdisciplinary Journal of Information, Knowledge, and Management. She is also the Vice President for Research Collaborations of the International Institute for Applied Knowledge Management. Ewa Ziemba has received numerous awards for research and teaching, including The Excellent Award of the President of the University of Economics in Katowice, The Silver Cross of Merit from the President of Poland, The Medal of the National Education Commission from the Ministry of National Education in Poland, The Award of Fellow \& Distinguished Scholar and The Excellence in Research \& Scholarship Award from the International Institute for Applied Knowledge Management, and several The Best Papers awards.

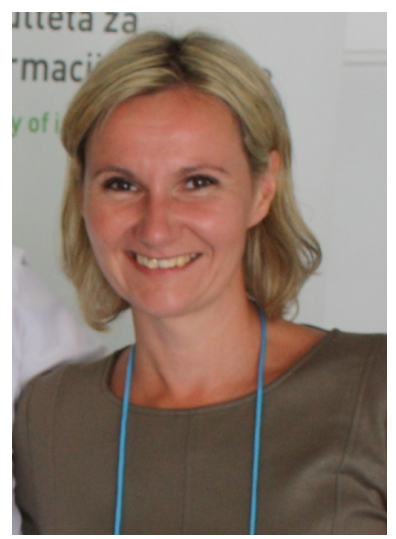

Monika Eisenbardt completed her Ph.D. with a major focus on management information systems as well as changes and challenges involving modern consumers. She is an Assistant Professor at the University of Economics in Katowice, Poland. Her current research focuses on consumers' knowledge and their willingness to knowledge sharing, as well as knowledge-based organizations. The background of her research is information and communication technologies. Monika Eisenbardt has published over 30 peer-reviewed pieces including conference papers, book chapters and international journal papers. She has received few Best Paper awards at the international conferences. Monika Eisenbardt serves Editorial Assistant function in Journal of Economics and Management - the official international journal of University of Economics in Katowice. 